\title{
Recursive Bit Assignment With Neural Reference Adaptive Step (RNA) MPPT Algorithm for Photoviolatic System
}

Eman Hegazy ( $\nabla$ eng.ehegazy2009@gmail.com )

Menoufia University

Mona Shokair

Menoufia University

waleed saad

Menoufia University

Original article

Keywords: MPPT, PV, ANFIS, NN, P\&O

Posted Date: May 24th, 2021

DOl: https://doi.org/10.21203/rs.3.rs-515759/v1

License: (1) (i) This work is licensed under a Creative Commons Attribution 4.0 International License.

Read Full License 


\title{
Recursive Bit Assignment With Neural Reference Adaptive Step (RNA) MPPT Algorithm for Photoviolatic System
}

\author{
Eman Hegazy ${ }^{1}$, Mona Shokair ${ }^{2}$ and Waleed Saad ${ }^{2,3}$ \\ ${ }^{1}$ Electronic and Electrical Comm. Dep., Faculty of Electronic Engineering, Menoufia University, Egypt, email:eng.ehegazy2009@gmail.com. \\ ${ }^{2}$ Electronic and Electrical Comm. Dep., Faculty of Electronic Engineering, Menoufia University, Egypt. \\ ${ }^{3}$ Electrical Engineering Department, College of Engineering, Shaqra University, Dawadmi, Ar Riyadh, Saudi Arabia.
}

\begin{abstract}
-

\section{A. Background}

Nowadays, most of the recent research is directed towards photovoltaic harvesting systems due to their great characteristics. To increase the efficiency of a photoviolatic harvesting system, Maximum Power Point Tracking algorithms are utilized to achieve the maximum output power of the PV. This is done by optimizing the duty ratio of the DC-DC boost converter.
\end{abstract}

\section{B. Results}

In this paper, a proposed RNA algorithm is introduced as an efficient MPPT algorithm for the PV system. This proposed RNA algorithm depends on two main parts. The First part is an artificial neural network to produce a reference power. The Second one is a proposed Recursive Bit Assignment network to present the variable step size of the duty ratio of the DC-DC boost converter. The RBA network consists of $N$-bit memory. The instantaneous PV power value sets the contents of the memory to generate the variable step size of the duty ratio. Moreover, the design of the neural network to give its best performance is explained.

\section{C. conclusions}

The performance of the chosen PV module is simulated for a variable solar radiation and a constant temperature. Simulation studies are performed using MATLAB to evaluate the system performance. From simulation results, the proposed RNA can achieve a fast tracking time, a high power efficiency, an actual maximum power point and an acceptable ripple. Additionally, comparisons between the RNA algorithm and other related algorithms such as Perturbe and Observe, Neural Network, and Adaptive Neural Interference System algorithms are executed. The proposed RNA achieves the best performance in all terms. Index Terms-MPPT, PV, ANFIS, NN, P\&O.

\section{INTRODUCTION}

Nowadays, solar PV energy is receiving a great deal of attention in the field of renewable energy sources. Solar PV in harvesting systems has been widely used in many high and low power applications such as wireless sensor networks. The solar PV cells convert the solar energy directly into electrical energy. Several solar PVs are combined to produce the PV module. The main challenge for PV harvesting system is its low efficiency as it is in the range of $10-40 \%$ [1].

Furthermore, the maximum output power of the PV changes under changing environmental conditions. In order to maximize the PV efficiency, Maximum Power Point Tracking (MPPT) algorithms are introduced for the PV systems. Its output power depends on the operating ratio of the switch in the DC-DC inductive boost converter which is connected with the PV module. Several MPPT algorithms have been developed to obtain the maximum power point (MPP) from the PV module [2].

The solar PV system is composed of PV module, DCDC boost converter, MPPT control circuit and load. The DCDC boost converters are used to raise the PV voltage to the required load voltage. It is worth mentioning that the working ratio of the DC-DC boost converter must be adjusted to obtain the MPP of the PV module. This can be done via the MPPT circuit.

In this paper, a proposed two-stage RNA algorithm combining NN and RBA is presented. In recent years, the neural network has become a more attractive issue due to its ability to solve non-linear and complex problems. Therefore, it is utilized in the proposed RNA algorithm. In the first stage, the $\mathrm{NN}$ is introduced for calculating the reference power value. Its front feed is used with two inputs which are irradiance $(\mathrm{G})$ and temperature (T). In the second stage, the RBA circuit is implemented to obtain the value of the variable step size of the DC-DC boost converter.

The proposed RNA algorithm adjusts the working duty ratio of the DC-DC boost converter to achieve the MPP of the solar PV module. The proposed system is studied using MATLAB. Many comparisons are made with other MPPT algorithms such as P\&O, NN, and ANFIS algorithms. The proposed algorithm can attain a fast rise time, a high power efficiency, an actual maximum power point which approximate the exact value and an allowable ripple.

The rest of the paper is organized as follows: Section II presents the related work. The description of the whole PV system architecture is shown in Section III. In Section IV, 
the proposed RNA algorithm is explained in details. The simulation analysis is provided in Section V. Finally, the conclusion remarks are shown in SectionVII .

\section{RELATED WORK}

Many algorithms are evolved to extract the Maximum Power Point from the solar PV module under varying conditions of solar irradiance and temperature [3]. The traditional techniques of MPPT algorithms which based on hill-climbing method such as Perturbation and Observation (P\&O), Incremental Conductance (INC), Fractional Open Circuit Voltage(OCV), and Fractional Short Circuit Current techniques have been discussed in [4]- [10]. These algorithms present a slow response under varying irradiation level. The heuristics based algorithms like particle swarm optimisation (PSO), Firefly Algorithm(FA), and genetic algorithm (GA) have been released to improve the MPPT performance under both partial shading and uniform irradiance climatic conditions as in [11]- [13]. The recent techniques such as artificial neural network [14][16], fuzzy logic methods [17]- [18], and artificial neuro-fuzzy inference system [19]- [20]. The artificial neural techniques become the most interested approaches that commonly used in PV systems due to its ability to resolve a significant problems of the traditional methods such as oscillation around the maximum point, failure behavior with rapid changing of the solar irradiance. Several MPPT controllers which based on the artificial neural network have been developed due to the main advantages of the neural network such as it can find complex nonlinear relations between the independent and dependent variables without need an accurate mathematical models. In [21], an artificial neural network has been introduced for fast tracking of maximum power point of the solar PV. In this algorithm, the output of the neural network is the reference voltage of the MPP of the solar PV under different climatic conditions. The authors present an efficient artificial neural network based MPPT scheme for improving the efficiency of the photovoltaic generator. It can be operated accurately and rapidly at MPP without power loss. This can be done through matching impedance between solar PV module and load by using a DC-DC boost converter in which its duty cycle is set by artificial NN. In [22], the authors have been proposed a two artificial neural network based MPPT controller: fixed step and variable step NN. The neural network based MPPT controller is executed in two steps: online and offline. Different set of neural network parameters are required to be trained through the offline step to find the optimal NN. The optimal neural network based MPPT controller can be used in the PV system through the online step. In [23], the authors have been investigated a low complexity MPPT algorithm which based on the neural network model of the solar PV. The expression for the output current of the NN model can explore a gradient, analytical MPPT method which can donate an accurate prediction of the maximum power. The proposed algorithm has a lower computational complexity than the other NNs based MPPT techniques as the position of the MPP is

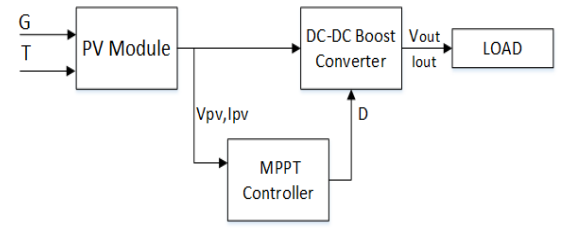

Fig. 1. The Solar PV harvesting system architecture.

determined by one multiplayer $\mathrm{NN}$ or by using two single layer NNs. Ref [24] provided an adaptive neuro-fuzzy system based MPPT algorithm with PI controller. The proposed algorithm donates a maximum power point tracker with a control gain for solar pumping system. Ref [25] improved the efficiency of the solar PV harvesting system by minimizing the energy losses caused by the MPPT controller and dc-dc converter. This can be done by using a successive approximation register based MPPT algorithm. This algorithm has a two main benefits rather than the other MPPT algorithms in terms of energy savings and power consumption. It is considered as an advanced version of hill climbing technique with a fast tracking time. Ref [25] suggested a maximum power point tracking circuit that used analog to digital converter with 4-bit successive approximation register for solar PV harvesting system. This circuit achieves high MPPT efficiency with a low power consumption.

\section{SYSTEM DESCRIPTION}

The architecture of the solar PV system consists of a PV module, a DC-DC boost converter, a MPPT control circuit, and a load. The main challenge for this system is the maximum power tracking process under different environmental conditions such as $\mathrm{G}$ and $\mathrm{T}$. The system architecture is plotted in Fig. 1.

The equivalent circuit of the solar PV module can be modeled as a single diode circuit as shown in Fig. 2. The mathematical expression for the nonlinear I-V characteristics of the ideal solar PV cell is described as follows [21]:

$$
I=I_{P V}-I_{o}\left[\exp \left(\frac{q v}{a K T}\right)-1\right]
$$

where, $I_{P V}$ is the photocurrent (generated current of the incident light). $I_{O}$ is the reverse saturation current. $\mathrm{q}$ is charge of electron $\left(1.6 \times 10^{-19} \mathrm{c}\right)$. $\mathrm{V}$ is the open circuit voltage. $\mathrm{K}$ is the Boltzmann constant $\left(1.38 \times 10-{ }^{19} \mathrm{~J} / \mathrm{K}\right), \mathrm{T}$ is the temperature of solar cell (300 kelvin) and $a$ is diode ideality constant. The output current of the PV module can be expressed as [23]:

$$
I=I_{P V}-I_{o}\left[\exp \left(\frac{q\left(V+I R_{s}\right)}{a K T}\right)\right]-\left(\frac{V+I R_{s}}{R_{p}}\right)
$$

where, $V$ is the output voltage. $R_{p}$ is the shunt resistance. $R_{s}$ is the series resistance.

\section{THE PROPOSED RECURSIVE BIT ASSIGNMENT WITH NEURAL REFERENCE ADAPTIVE STEP (RNA) ALGORITHM}

The proposed RNA algorithm consists of two main steps. First, the feed forward neural network is used. It has two 


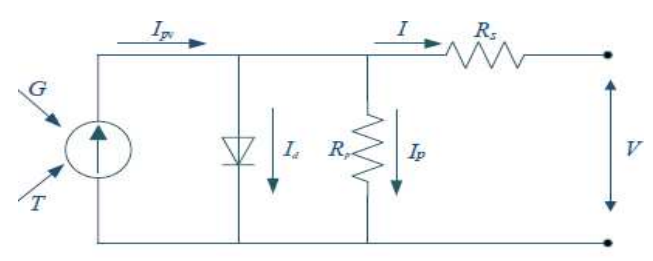

Fig. 2. The equivalent circuit model of the PV module.

inputs which are the radiation $\mathrm{G}$ and the temperature $\mathrm{T}$. Hence, the maximum power point $P_{m p p}$ is the output of the neural network. It can be used as a reference power for the second step. The second step is the recursive bit allocation which is used to obtain the adaptive duty cycle.

\section{A. The Proposed RNA Architecture}

The flowchart of the proposed algorithm is shown in Fig. 3. It can be explained as follows:

Firstly, the initialization parameters which are the initial value of power $\left(P_{\text {old }}=0\right)$, the initial value of the duty cycle $\left(D_{\text {old }}\right)$ and the fixed step size $(d=0.00001)$ are set. $D_{\text {old }}$ can be donated as follows:

$$
D_{\text {old }}=D_{\min }+\operatorname{rand} *\left[D_{\max }-D_{\min }\right]
$$

where, $D_{\max }$ is the maximum duty ratio, $D_{\min }$ is the minimum duty ratio, and rand is a random value from 0 to 1.

Then, the irradiance $(\mathrm{G})$ and the temperature $(\mathrm{T})$ are measured. These values are used as inputs for both the PV and the NN modules. The outputs of the PV module are the voltage $\left(V_{p v}\right)$ and current $\left(I_{p v}\right)$ of the PV. Thereafter, the PV power can be calculated by multiplying $\left(V_{p v}\right)$ and $\left(I_{p v}\right)$. Hence, the power difference $(d P)$ can be estimated by subtracting the $P_{\text {old }}$ from the instantaneous PV power value.

After that, RBA algorithm is performed to estimate the variable step size of the duty ratio. It consists of a memory with a length of $N$ bits. After the $N$ bits are assigned, the aggregated value $(B)$ is calculated. The architecture of the whole RBA block is drawn in Fig. 4.

Afterwards, the outputs of both the NN module $\left(P_{r e f}\right)$ and the RNA module (B) are used to calculate the variable step size $(\triangle D)$ as indicated in the following equation:

$$
\triangle D=\left(P_{\text {old }}-P_{\text {ref }}\right) * d * B
$$

Finally, the value of the duty ratio $(D)$ is calculated as

$$
D=\left(D_{\text {old }}+\triangle D\right)
$$

where $D=\left(D_{\text {old }}+\triangle D\right)$ when $d P<0$. Otherwise, $D=$ $\left(D_{\text {old }}-\triangle D\right)$. This condition can be implemented using a

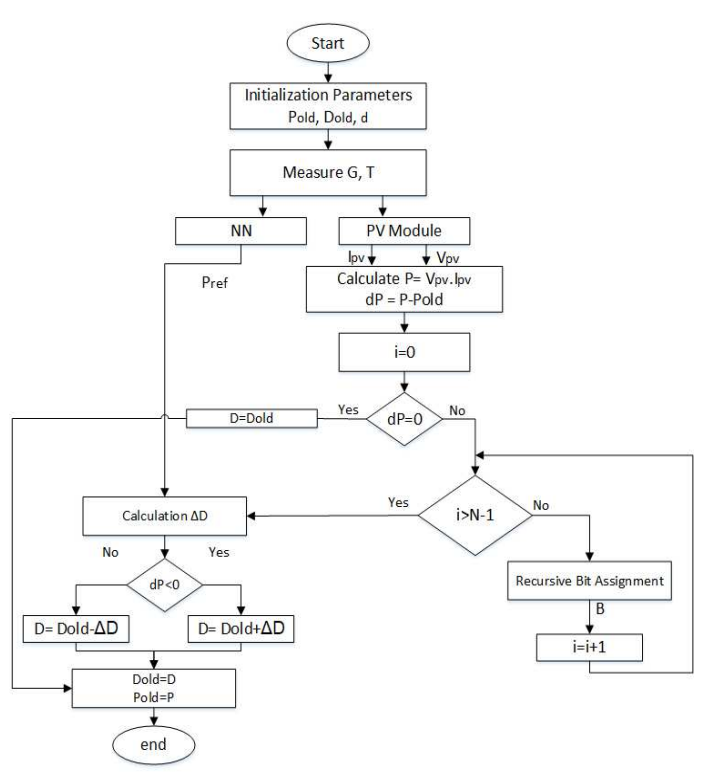

Fig. 3. The flowchart of the proposed RNA algorithm.

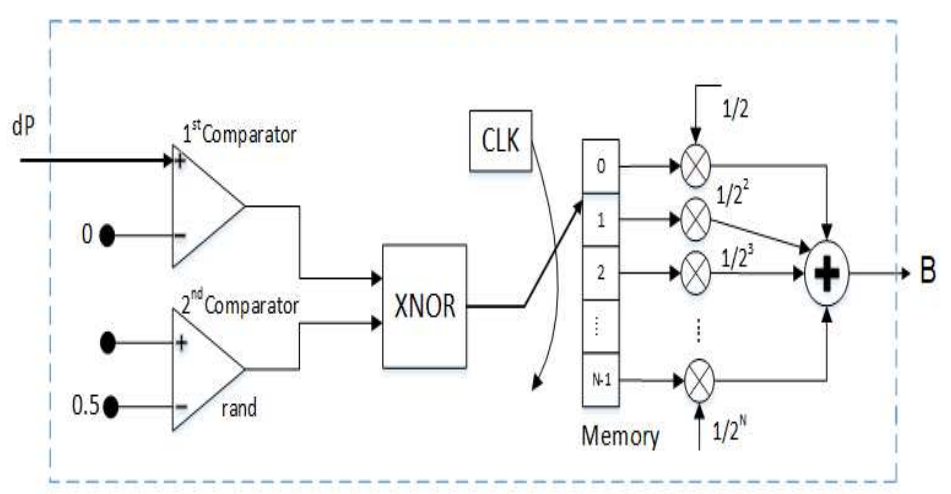

Fig. 4. The Recursive Bit Assignment (RBA) Block.

comparator circuit. The hardware architecture of the proposed harvesting system using RBA algorithm is shown in Fig. 5.

\section{B. Recursive Bit Assignment (RBA)}

As shown in Fig. 4, the RBA block consists of two comparators, X-NOR, memory with size of $N * 1$ bits, $N$ multipliers and one adder.

First, $d P$ is compared with zero. Then, the output of the comparator is X-nored with a rand comparator. The X-NOR circuit operation is listed in Table I. Hence, the output of the X-NOR circuit is stored in a sequentially manner in the memory locations.

After all memory contents are assigned ( $B_{0}$, $\left.B_{(} N-1\right)$ ), the output of RBA block can be determined by summing the weighted values of the assigned bits which can be written as: 


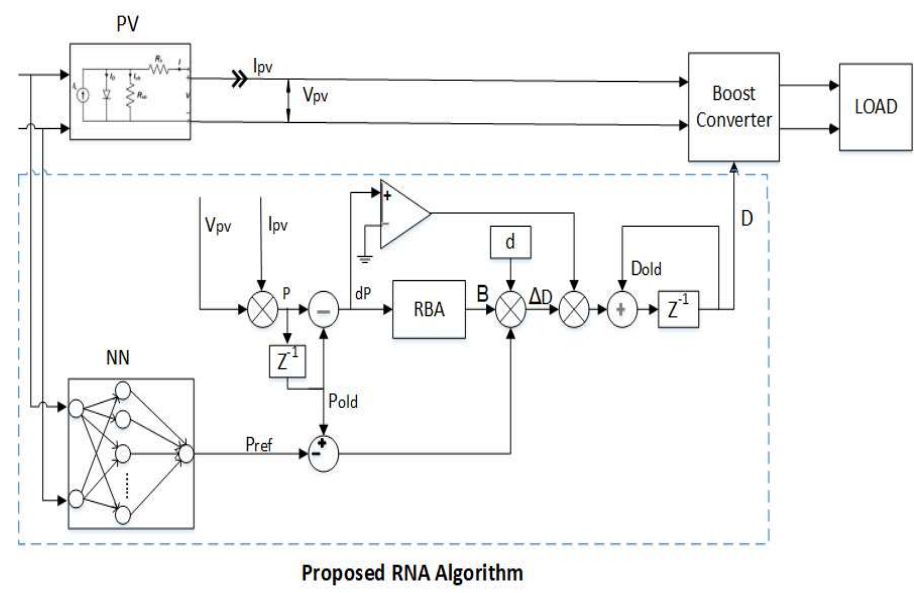

Fig. 5. The proposed harvesting system architecture using RNA MPPT algorithm.

TABLE I

THE X-NOR CIRCUIT OPERATION

\begin{tabular}{ccc}
\hline first comparator & second comparator & X-NOR output \\
\hline 0 & 0 & 1 \\
0 & 1 & 0 \\
1 & 0 & 0 \\
1 & 1 & 1 \\
& \\
$B=\left[\frac{B_{0}}{2^{1}}+\frac{B_{1}}{2^{2}}+\ldots \ldots \ldots . . . \frac{B_{N-1}}{2^{N}}\right]$
\end{tabular}

\section{Neural Network based MPPT}

In this research, feed forward neural network with one hidden layer of 10 neurons is used for the MPPT control design. It has two inputs (which are $\mathrm{G}$ and $\mathrm{T}$ ) and one output variable $\left(P_{m p p}\right)$ as shown in Fig. 5. The training process for the neural network is performed using Levenberg-Marquardt back propagation optimization method.

\section{Simulation AnAlysis}

\section{A. Simulation Setup}

The whole proposed harvesting system architecture using RNA MPPT algorithm is designed using MATLAB. The proposed system uses a PV module of Soltech 1STH-250WH type with a maximum power of 250 Watt. The numerical parameters values of the PV type is listed in TABLE II. The nonlinear P-V and I-V characteristics of the PV module for different values of irradince from 200 to $1000 \mathrm{~W} / \mathrm{m}^{2}$ are shown in Fig. 6.

\section{B. Neural Network Performance}

The relation between the Mean Square Error (MSE) with number of epochs of the NN performance is shown in Fig. 7. The training, validation, and testing measurements are plotted. From results, the best validation performance is MSE of
TABLE II

THE PV MODULE SPECIFICATIONS AT $1000 \mathrm{~W} / \mathrm{m}^{2}$ AND TEMPERATURE OF $25^{\circ} \mathrm{C}$

\begin{tabular}{cc}
\hline Parameters & Values \\
\hline Open circuit voltage, $V_{O C}$ & $37.3 \mathrm{~V}$ \\
\hline Short circuit current, $I_{S C}$ & $8.66 \mathrm{~A}$ \\
\hline Cells in a module, $N$ & 60 \\
\hline Ideality factor, $A$ & 1.019 \\
\hline Parallel Resistance, $R_{p}$ & $224.1886 \Omega$ \\
\hline Series Resistance, $R_{s}$ & $0.23724 \Omega$ \\
\hline
\end{tabular}
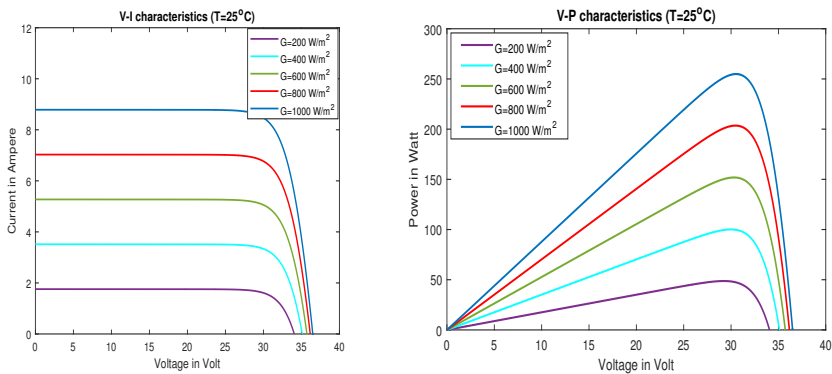

Fig. 6. The V-I and V-P characteristic of the PV module.

$9.0106 \times 10^{-5}$ at 1000 epochs. Additionally, all the training, the validation, and the testing curves are closed to each others. That is means that the designed $\mathrm{NN}$ is reliable and it can efficiently predict its output value.

\section{The Proposed RNA Algorithm Performance}

Fig. 8 draws the input irradiance pattern which is applied to the selected PV module. It begins with $1000 \mathrm{~W} / \mathrm{m}^{2}$. Then, it changes from 1000 to 800 and $600 \mathrm{~W} / \mathrm{m}^{2}$ with a step time of $0.4 \mathrm{sec}$.

The proposed RNA system performance is measured in terms of three main parameters, which are: the achievement the MPP, the fulfillment the high speed in tracking the MPP and the reduction of the ripple around the MPP. The PV output and PV powers and the boost converter output voltage and output current curves are shown from Fig. 9 to Fig. 12. From

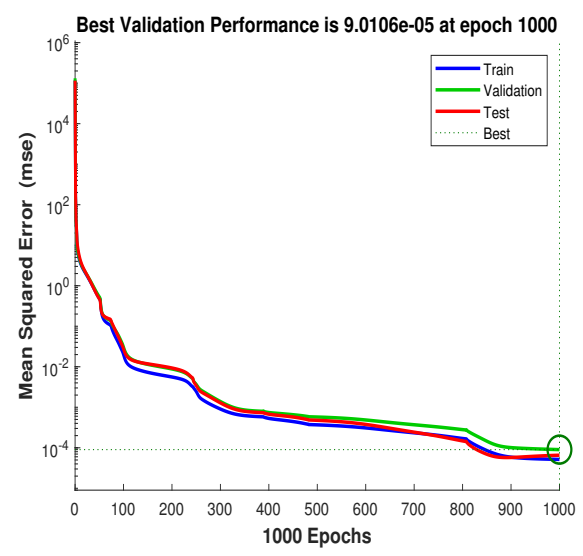

Fig. 7. The performance of the Neural Network. 


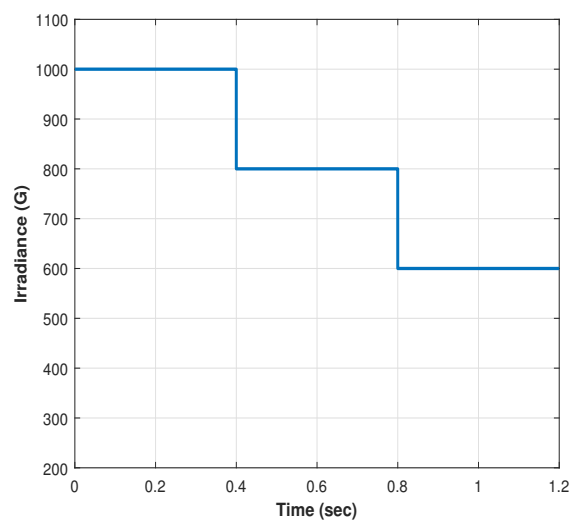

Fig. 8. The Input irradiance pattern.

results, the proposed RNA algorithm achieves the MPP with fast tracking response and acceptable oscillations around the MPP.

Fig. 9 shows a comparison of the output powers of the DC-DC boost converter for the proposed RNA, ANFIS, NN, and $\mathrm{P} \& \mathrm{O}$ algorithms. It is obviously that the proposed RNA system achieves the best performance compared with other algorithms. It achieves the fastest time response with the irradiance variation. Also, it has an acceptable ripple. This is because the utilization of the RBA block that continues fine tuning the duty ratio of the boost converter. Additionally, the performance can be improved by increasing the memory size of the RBA block. This can be done by increasing the number of the bits to properly achieve the maximum power point. At $\mathrm{G}=1000 \mathrm{~W} / \mathrm{m}^{2}, 800 \mathrm{~W} / \mathrm{m}^{2}$, and $600 \mathrm{~W} / \mathrm{m}^{2}$, the proposed algorithm attains maximum output power of $245 \mathrm{~W}$, $195 \mathrm{~W}$, and $146 \mathrm{~W}$, respectively with fast tracking response. While, the NN-based and ANFIS algorithms have a slow responses with less maximum power point values. Whereas, the conventional $\mathrm{P} \& \mathrm{O}$ provides the worst performance in terms of tracking response compared with all other algorithms. At $\mathrm{G}=1000 \mathrm{~W} / \mathrm{m}^{2}$, the proposed system attains the maximum power value within $0.05 \mathrm{sec}$. While, the ANFIS and NN-based algorithms arrive a maximum power of $237 \mathrm{~W}$ and $236 \mathrm{~W}$ within $0.17 \mathrm{sec}$ and $0.12 \mathrm{sec}$, respectively.

The comparison of the PV powers of the DC-DC boost converter for the proposed RNA, ANFIS, NN, and P\&O algorithms is shown in Fig. 10. It is cleared that the best performance is occurred with the proposed RNA system in terms of all comparison metrics. At $\mathrm{G}=1000 \mathrm{~W} / \mathrm{m}^{2}$, the proposed algorithm achieves a maximum PV power of $249 \mathrm{~W}$ at $0.05 \mathrm{sec}$. While, the other algorithms have more delays to reach the maximum power point value. At $\mathrm{G}=800 \mathrm{~W} / \mathrm{m}^{2}$, ANFIS algorithm begins with a low PV power of $180 \mathrm{~W}$ at $\mathrm{t}=0.4$ sec. It arrives the maximum PV power of $195 \mathrm{~W}$ at $\mathrm{t}=0.44 \mathrm{sec}$. The proposed algorithm approximately gets a stable PV power value of $198 \mathrm{~W}$ at $\mathrm{t}=0.4 \mathrm{sec}$. Whereas, the NN-based algorithm performs nearly the same response of ANFIS with a low PV power of $142 \mathrm{~W}$ at $0.4 \mathrm{sec}$. While the

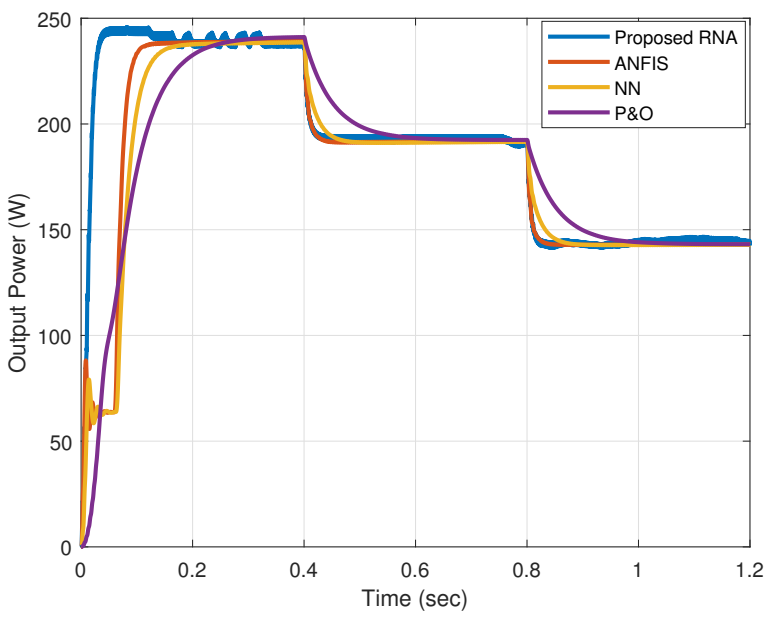

Fig. 9. The output power of the proposed RNA algorithm.

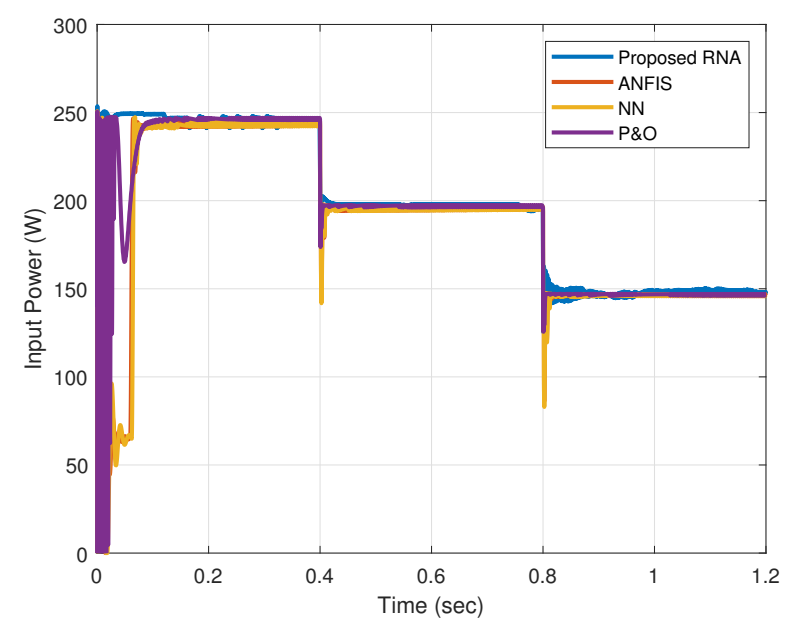

Fig. 10. The PV power of the proposed RNA algorithm.

$\mathrm{P} \& \mathrm{O}$ arrives a value of $173 \mathrm{~W}$ at $\mathrm{t}=0.4 \mathrm{sec}$ and a maximum value of $198 \mathrm{~W}$ at $0.44 \mathrm{sec}$.

The output voltages of the DC-DC boost converter for the compared algorithms are shown in Fig. 11. For $\mathrm{G}=1000 \mathrm{~W} / \mathrm{m}^{2}$, the proposed algorithm has the fastest response to arrive the maximum output voltage at $70 \mathrm{~V}$ within $0.05 \mathrm{sec}$. While, the ANFIS requires about $0.14 \mathrm{sec}$ to get a maximum output voltage of 69 V.W Whereas, the NN-based algorithm needs $0.2 \mathrm{sec}$ to obtain the same performance as the ANFIS algorithm. Regarding to the $\mathrm{P} \& \mathrm{O}$, it has a slow response, as it needs more time of $0.3 \mathrm{sec}$ to follow up the same performance of the two previous algorithms.

Fig. 12 demonstrates the output currents for all compared algorithms. The proposed algorithm reaches the maximum output current value of $3.5 \mathrm{~A}$ at a time of $0.05 \mathrm{sec}$. At $\mathrm{G}=800 \mathrm{~W} / \mathrm{m}^{2}$, the proposed algorithm obtains the maximum output current value of $3.1 \mathrm{~A}$ at $0.4 \mathrm{sec}$. The ANFIS algorithm has faster response than the NN-based 


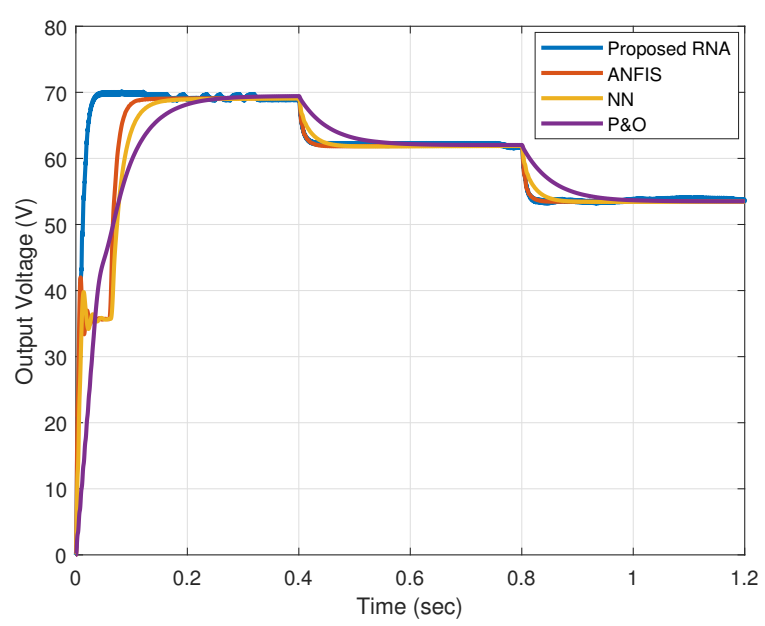

Fig. 11. The output voltage of the proposed RNA algorithm.

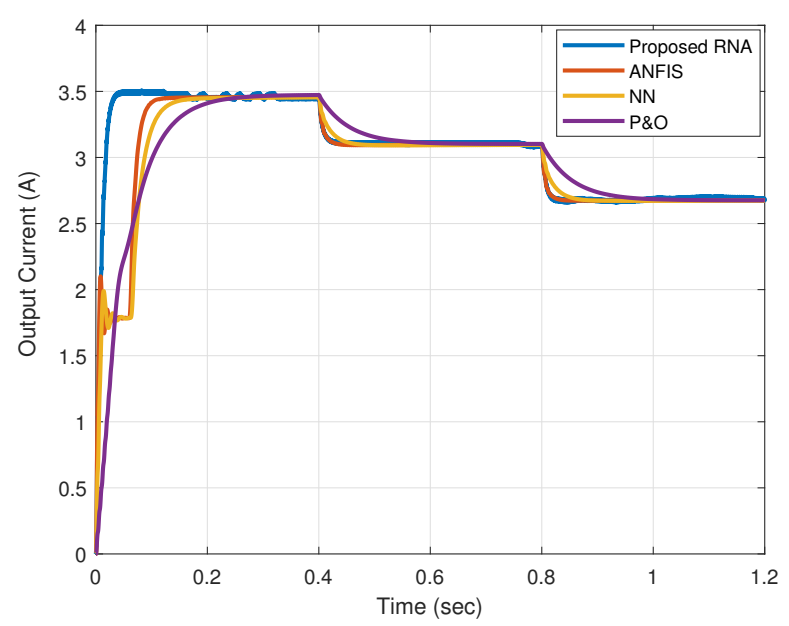

Fig. 12. The output current of the proposed RNA algorithm.

algorithm. While, the $\mathrm{P} \& \mathrm{O}$ algorithm has the highest delay as it needs a time of $0.57 \mathrm{sec}$ to achieve the maximum value. Also, at $\mathrm{G}=600 \mathrm{~W} / \mathrm{m}^{2}$, the proposed algorithm donates a maximum current of $2.7 \mathrm{~A}$ at $0.84 \mathrm{sec}$. The NN-based algorithm needs $0.03 \mathrm{sec}$ to reach the same performance as the ANFIS algorithm. While, the $\mathrm{P} \& \mathrm{O}$ algorithm requires $1 \mathrm{sec}$ to arrive the maximum output current.

The metric of "MPP achievement" can be measured using "algorithm efficiency" metric. The algorithm efficiency can be defined as:

efficiency $=1-\left[\frac{\left(M P P_{a} \text { lgorithm }-M P P_{a} \text { ctual }\right)}{M P P_{a} \text { ctual }}\right] * 100$

where, $M P P_{\text {algorithm }}$ is the obtained MPP by the algorithm. Also, the ripple around the MPP can be measured by "the ripple factor". It can be defined as the difference between the maximum and the minimum power values divided by the minimum power value at the steady state. The summary of the comparisons between the proposed RNA algorithm and the other three MPPT algorithms (ANFIS, NN-based, and P\&O) with different irradiance levels $\left(1000,800,600 \mathrm{~W} / \mathrm{m}^{2}\right)$ are listed in TABLE III. The most important metrics are the rise time (the fast tacking response), the algorithm efficiency, and the ripple factor.

\section{DeClarations}

\section{A. Data Availability}

All data sets in this paper are normally available to publishing. Also, the data that support the findings of this paper are available from the corresponding author upon reasonable request. Moreover, the data are not publicly available due privacy.

\section{B. Competing interests}

This paper includes a competing interests with other related works.

\section{C. funding}

There is no funding source.

\section{Acknowlegements}

The authors declare no conflict of interest and no financial support. The authors encourage the readers to use all data sets and results in this paper.

\section{CONCLUSIONS}

The proposed RNA MPPT controller for solar PV system has been presented. It has been consisted of two main stages which are; the neural stage and the RBA algorithm stage. The neural stage has been used to obtain the reference power. While, the RBA stage has been utilized to determine the variable step of the duty ratio for the boost converter. Comparisons between the proposed algorithm and other techniques such as; ANFIS, NN-based, and P\&O have been executed. From the simulation results, the proposed algorithm has achieved the superior performance in terms of both the fast tacking of the MPP and the efficiency. While, it has reaped a slightly higher ripple compared with other algorithms.

\section{REFERENCES}

[1] M. Prauzek, J. Konecny, M. Borova, K. Janosova, J. Hlavica and P. Musilek, "Energy harvesting sources, storage devices and system topologies for environmental wireless sensor networks: A review," Sensors, vol. 18, no.8, pp. 2446, Aug 2018.

[2] B. Bendib,H. Belmili, and F. Krim, " A survey of the most used MPPT methods: Conventional and advanced algorithms applied for photovoltaic systems," Renewable and Sustainable Energy Reviews, vol.45, pp.637648, 2015.

[3] Pakkiraiah, B., and G. Durga Sukumar. "Research survey on various MPPT performance issues to improve the solar PV system efficiency." Hindawi Publishing Corporation Journal of Solar Energy, (2016).

[4] Patel, A., Kumar, V., and Kumar, Y., "Perturb and observe maximum power point tracking for Photovoltaic cell," Innovative Systems Design and Engineering, vol. 4, no. 6, pp. 9-15, 2013. 
TABLE III

The Collected Data of the Proposed Algorithm and Other Algorithms Results.

\begin{tabular}{|c|c|c|c|c|c|c|c|c|}
\hline Parameter & $\begin{array}{c}\text { Irradiance } \\
W / m^{2}\end{array}$ & $\begin{array}{c}\text { Output Voltage } \\
V\end{array}$ & $\begin{array}{l}\text { Output Power } \\
\text { Watt }\end{array}$ & $\begin{array}{l}\text { MPP } P_{\text {Algorithm }} \\
\text { Watt }\end{array}$ & $\begin{array}{c}M P P_{\text {Actual }} \\
\text { Watt }\end{array}$ & $\begin{array}{c}\text { Rise time } \\
\text { sec }\end{array}$ & $\begin{array}{c}\text { Efficiency } \\
\%\end{array}$ & Ripple Factor \\
\hline \multirow{3}{*}{ Proposed } & 1000 & 69.76 & 243 & 247.4 & 250 & 0.052 & $98.9 \%$ & 0.436 \\
\hline & 800 & 62.3 & 194.3 & 197.87 & 200 & 0.43 & $98.9 \%$ & 0.53 \\
\hline & 600 & 54 & 145.6 & 148.92 & 150 & 0.87 & $99.28 \%$ & 0.52 \\
\hline \multirow{3}{*}{ ANFIS } & 1000 & 69 & 238.7 & 244.62 & 250 & 0.13 & $97.84 \%$ & 0.202 \\
\hline & 800 & 61.9 & 192.7 & 196.65 & 200 & 0.45 & $98.3 \%$ & 0.08 \\
\hline & 600 & 53.5 & 143.07 & 146.5 & 150 & 0.85 & $97.66 \%$ & 0.05 \\
\hline \multirow{3}{*}{ NN } & 1000 & 68.9 & 238 & 244 & 250 & 0.18 & $97.6 \%$ & 0.062 \\
\hline & 800 & 61.8 & 191.27 & 196.4 & 200 & 0.489 & $98.2 \%$ & 0.03 \\
\hline & 600 & 53.4 & 142.75 & 145.95 & 150 & 0.892 & $97.3 \%$ & 0.01 \\
\hline \multirow{3}{*}{$\mathrm{P} \& \mathrm{O}$} & 1000 & 69.1 & 240 & 246 & 250 & 0.3 & $98.4 \%$ & 0.027 \\
\hline & 800 & 62 & 192.8 & 197 & 200 & 0.6 & $98.4 \%$ & 0.01 \\
\hline & 600 & 53.5 & 143.2 & 146.7 & 150 & 1 & $97.8 \%$ & 0.01 \\
\hline
\end{tabular}

[5] M.L, Azad, S, Das, P, Kumar Sadhu, B, Satpati, A, Gupta and P, Arvind (2017), "P\&O algorithm based MPPT technique for solar PV system under different weather conditions," International Conference on Circuit ,Power and Computing Technologies (ICCPCT).

[6] S, Salman, A.I, Xin and W.Y, Zhouyang (2018), " Design of a P-\&-O algorithm based MPPT charge controller for a stand-alone 200W PV system," Protection and Control of Modern Power Systems, Vol.3(1), pp. 1-8.

[7] K. S. Tey and S. Mekhilef, "Modified incremental conductance MPPT algorithm to mitigate inaccurate responses under fastchanging solar irradiation level,' Solar Energy, vol. 101, pp. 333- 342, 2014.

[8] Chuang, M.T., Liu, Y.H. and Ye, S.P., 2020. A Novel Variable Step Size Incremental Conductance Method with an Adaptive Scaling Factor. Applied Sciences, 10(15), p.5214.

[9] Bharath, K. R., \& Suresh, E. (2017). Design and implementation of improved fractional open circuit voltage based maximum power point tracking algorithm for photovoltaic applications. International Journal of Renewable Energy Research (IJRER), 7(3), 1108-1113.

[10] Sher, H. A., Murtaza, A. F., Noman, A., Addoweesh, K. E., \& Chiaberge, M. (2015). An intelligent control strategy of fractional short circuit current maximum power point tracking technique for photovoltaic applications. journal of renewable and sustainable Energy, 7(1), 013114.

[11] K. Sundareswaran, S. Peddapati and S. Palani (2014), "MPPT of PV systems under partial shaded conditions through a colony of flashing fireflies," IEEE transactions on energy conversion, Vol.29(2), pp.463-472.

[12] Xu, L., Cheng, R., Xia, Z., \& Shen, Z. (2020, May). Improved Particle Swarm Optimization (PSO)-based MPPT Method for PV String under Partially Shading and Uniform Irradiance Condition. In 2020 Asia Energy and Electrical Engineering Symposium (AEEES) (pp. 771-775). IEEE.

[13] Chitra, A., Yogitha, G., Sivaramakrishnan, K., Razia Sultana, W., \& Sanjeevikumar, P. (2020). Modified Firefly-Based Maximum Power Point Tracking Algorithm for PV Systems Under Partial Shading Conditions. Artificial Intelligent Techniques for Electric and Hybrid Electric Vehicles, 143-163.

[14] Berrezzek, F., Khelil, K., \& Bouadjila, T. (2020, May). Efficient MPPT scheme for a photovoltaic generator using neural network. In 020 1st International Conference on Communications, Control Systems and Signal Processing (CCSSP) (pp. 503-507). IEEE.

[15] Allahabadi, S., Iman-Eini, H.,\& Farhangi, S. (2019, February). Neural network based maximum power point tracking technique for PV arrays in Mobile Applications. In 2019 10th International Power Electronics, Drive Systems and Technologies Conference (PEDSTC) (pp. 701-706). IEEE.

[16] Aziz, M. S., \& Hamad, B. A. (2020). Comparison between neural network and $\mathrm{P} \& \mathrm{O}$ method in optimizing MPPT control for photovoltaic cell. International Journal of Electrical and Computer Engineering, 10(5), 5083.
[17] Jose, B. K. (2020). Fuzzy Based Maximum Power Point Tracking of PV Array under Non-uniform Irradiance Conditions. Materials Today: Proceedings, 24, 1835-1842.

[18] Robles Algarín, C., Taborda Giraldo, J., \& Rodríguez Álvarez, O. (2017). Fuzzy logic based MPPT controller for a PV system. Energies, 10(12), 2036.

[19] Amara, K., Fekik, A., Hocine, D., Bakir, M. L., Bourennane, E. B., Malek, T. A., \& Malek, A. (2018, October). Improved performance of a PV solar panel with adaptive neuro fuzzy inference system ANFIS based MPPT. In 2018 7th International Conference on Renewable Energy Research and Applications (ICRERA) (pp. 1098-1101). IEEE.

[20] Abido, M. A., Khalid, M. S., \& Worku, M. Y. (2015). An efficient ANFIS-based PI controller for maximum power point tracking of PV systems. Arabian Journal for Science and Engineering, 40(9), 2641-2651.

[21] Sedaghati, F., Nahavandi, A., Badamchizadeh, M. A., Ghaemi, S., \& Abedinpour Fallah, M. (2012). PV maximum power-point tracking by using artificial neural network. Mathematical Problems in Engineering, 2012.

[22] Messalti, S., Harrag, A., \& Loukriz, A. (2017). A new variable step size neural networks MPPT controller: Review, simulation and hardware implementation. Renewable and Sustainable Energy Reviews, 68, 221233.

[23] Zečević, Žarko, and Maja Rolevski. "Neural network approach to MPPT control and irradiance estimation.” Applied Sciences 10, no. 15 (2020): 5051 .

[24] Hepzibah, A. A., \& Premkumar, K. (2020). ANFIS current-voltage controlled MPPT algorithm for solar powered brushless DC motor based water pump. Electrical Engineering, 102(1), 421-435.

[25] Abraham, N. T., Kumar, K. V., Jose, V., Mathew, D. M., \& Kumar, S. S. (2013). SAR Algorithm Method in Photovoltaic System using MPPT. International Journal of Power Electronics and Drive Systems, 3(4), 438.

[26] Choi, E., Kim, J., Lee, T., Namgoong, G., \& Bien, F. (2020, November). Fast Maximum Power Point Tracking Technique With 4-Bits/Cycle SAR ADC For Photovoltaic Energy Harvesting System. In 2020 IEEE Wireless Power Transfer Conference (WPTC) (pp. 163-165). IEEE. 
Figures

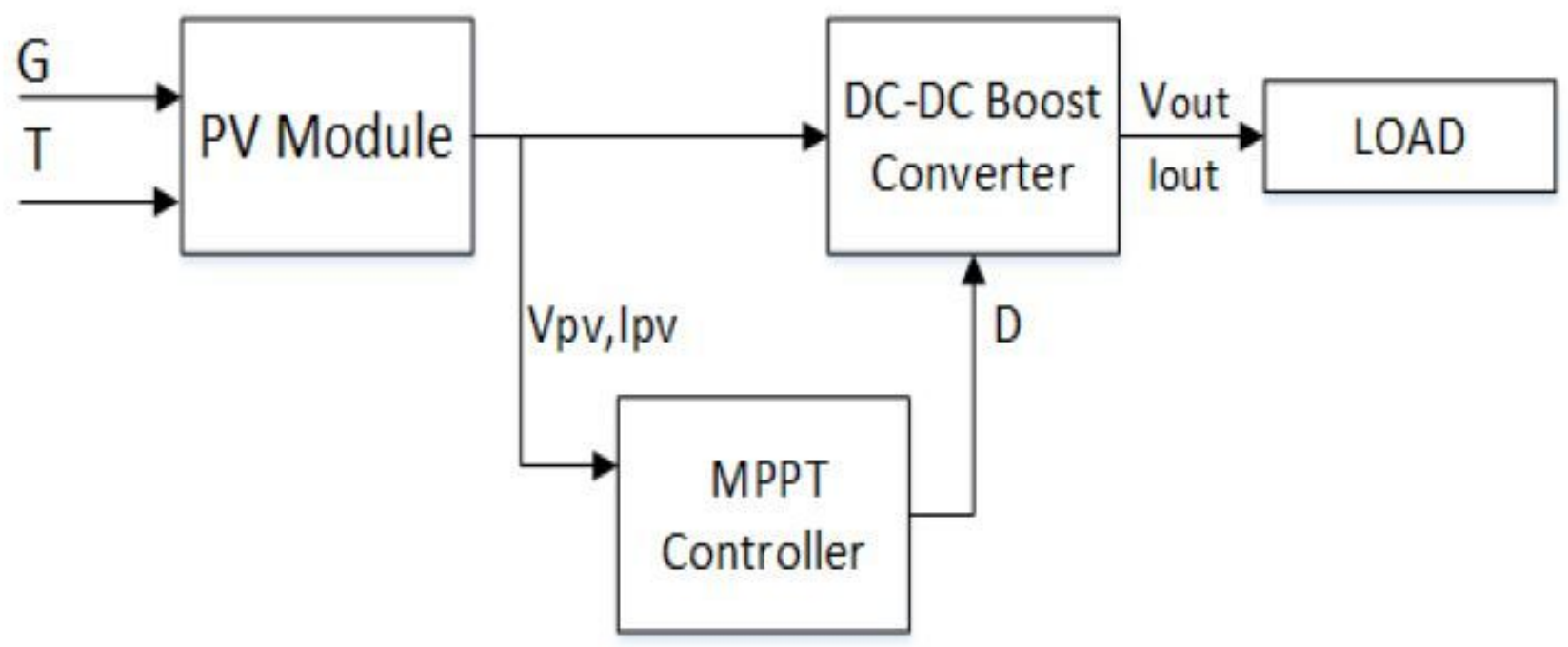

Figure 1

The Solar PV harvesting system architecture.

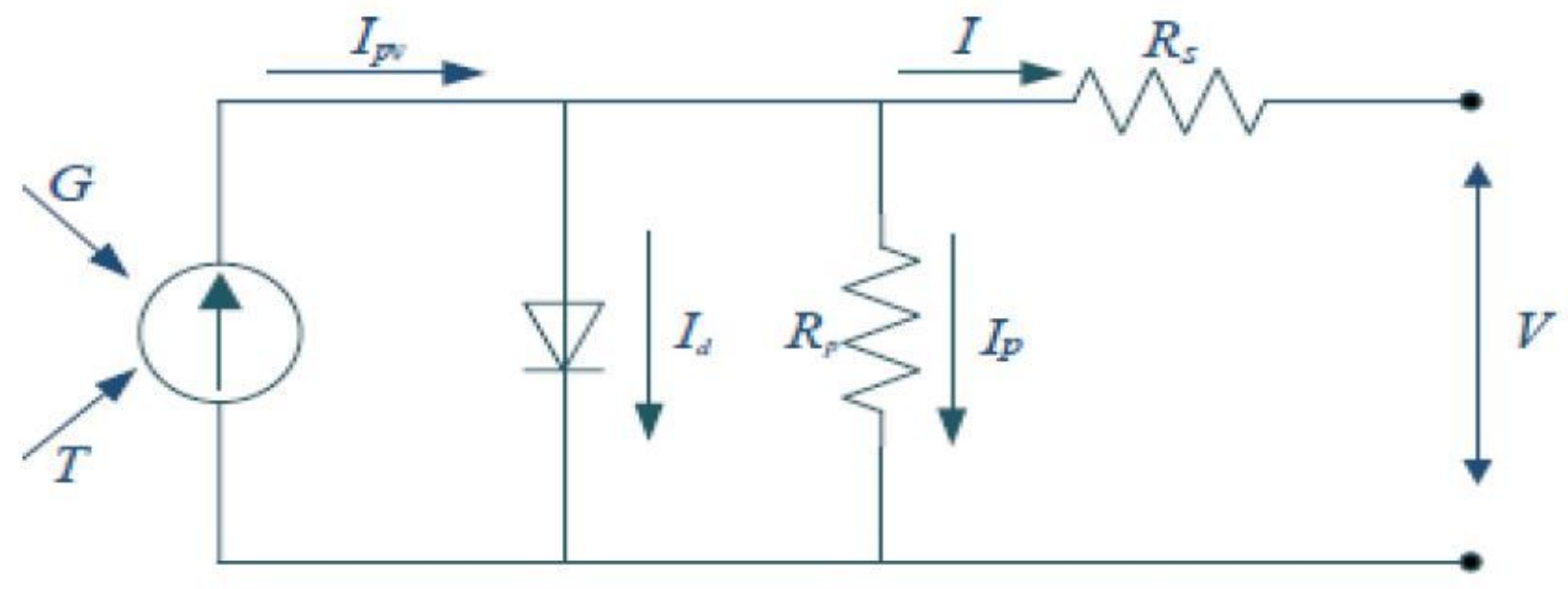

Figure 2

The equivalent circuit model of the PV module. 


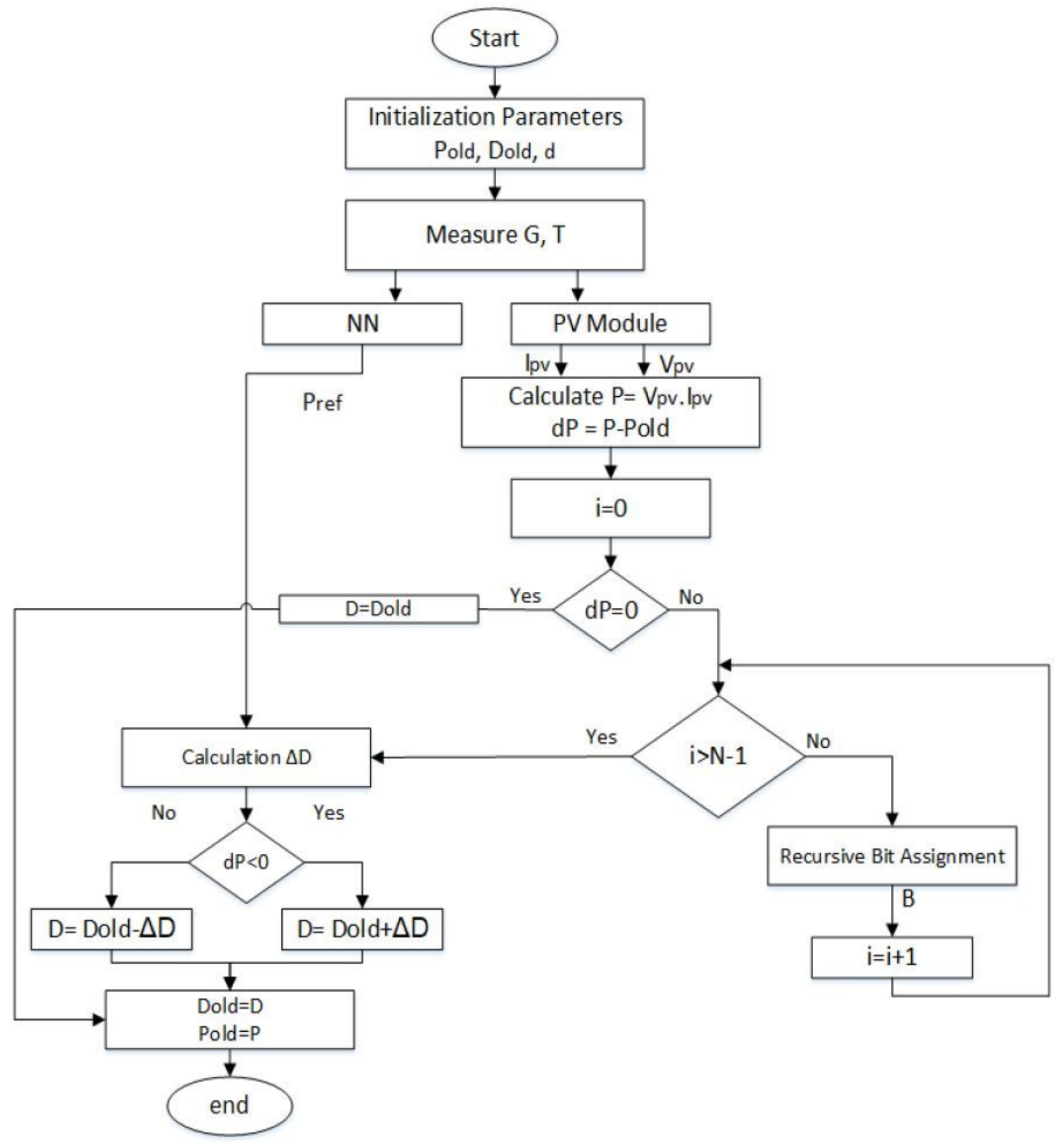

Figure 3

The flowchart of the proposed RNA algorithm. 


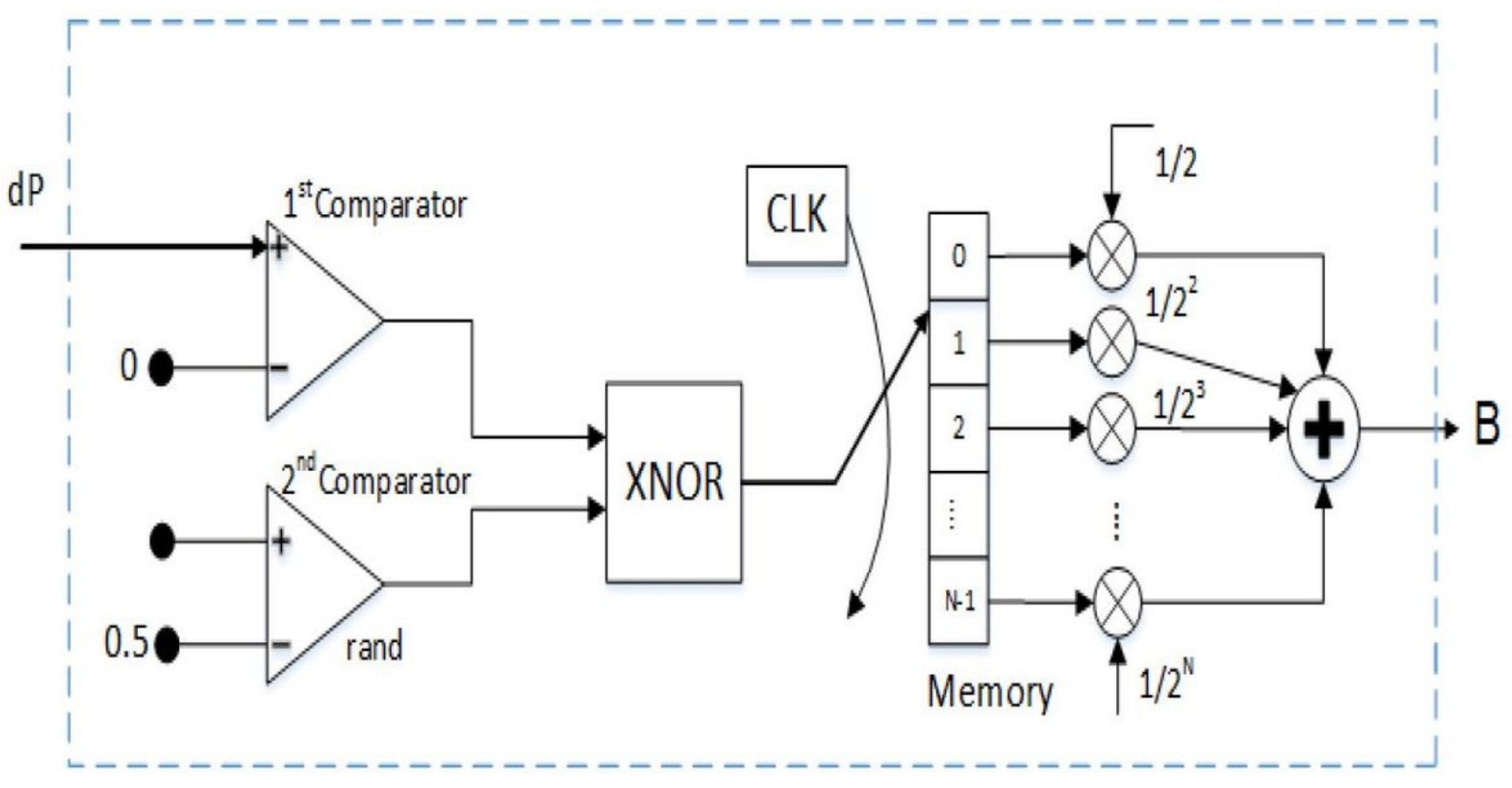

Figure 4

The Recursive Bit Assignment (RBA) Block. 


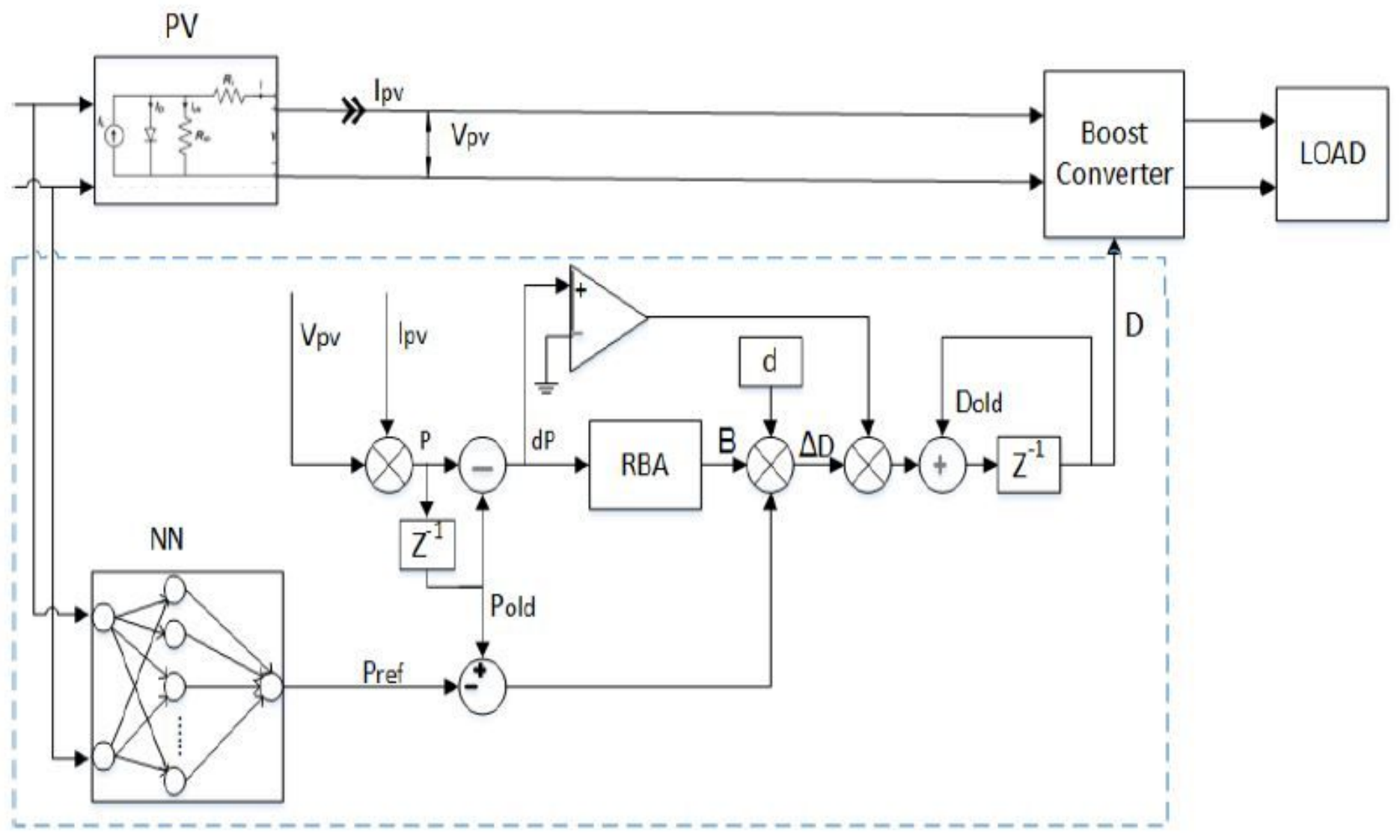

Proposed RNA Algorithm

Figure 5

The proposed harvesting system architecture using RNA MPPT algorithm.
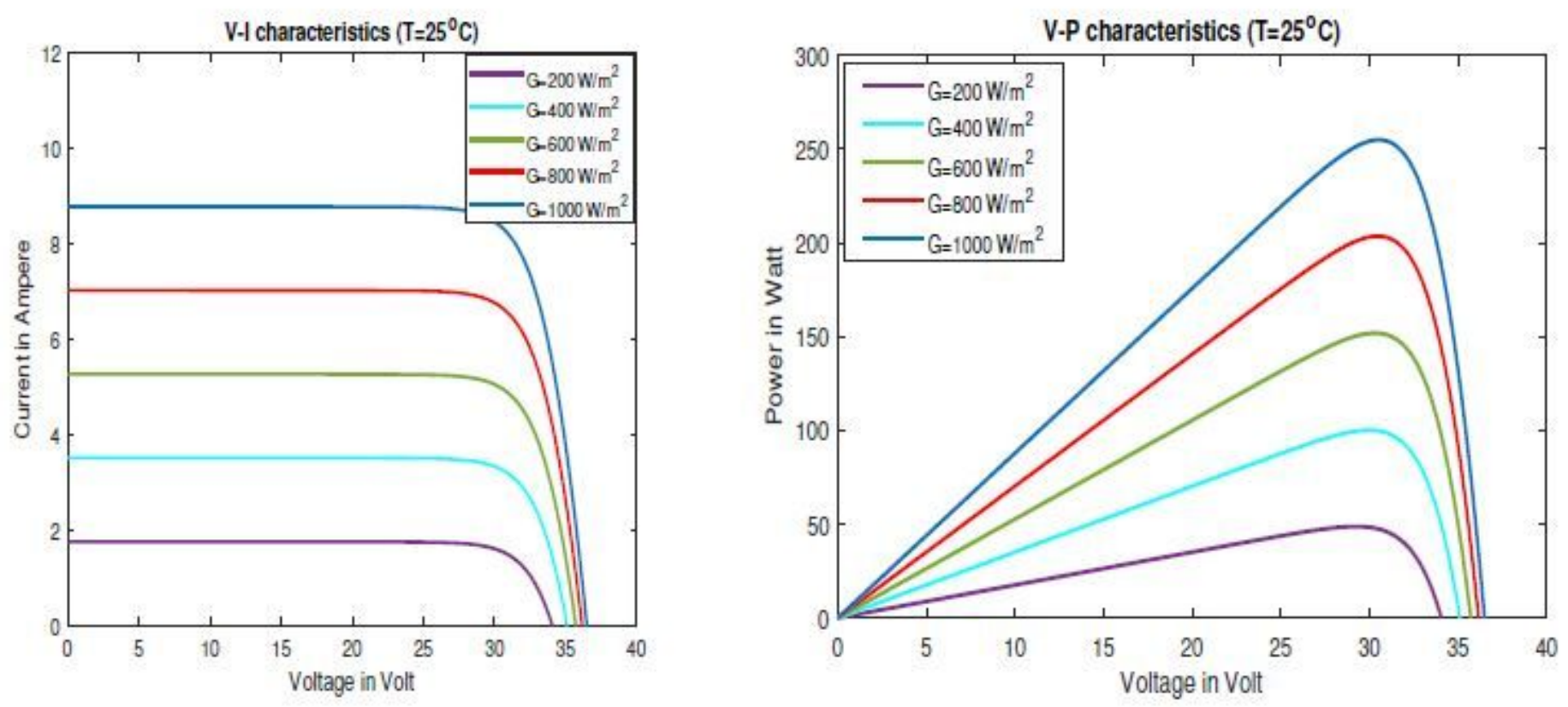
Figure 6

The V-I and V-P characteristic of the PV module.

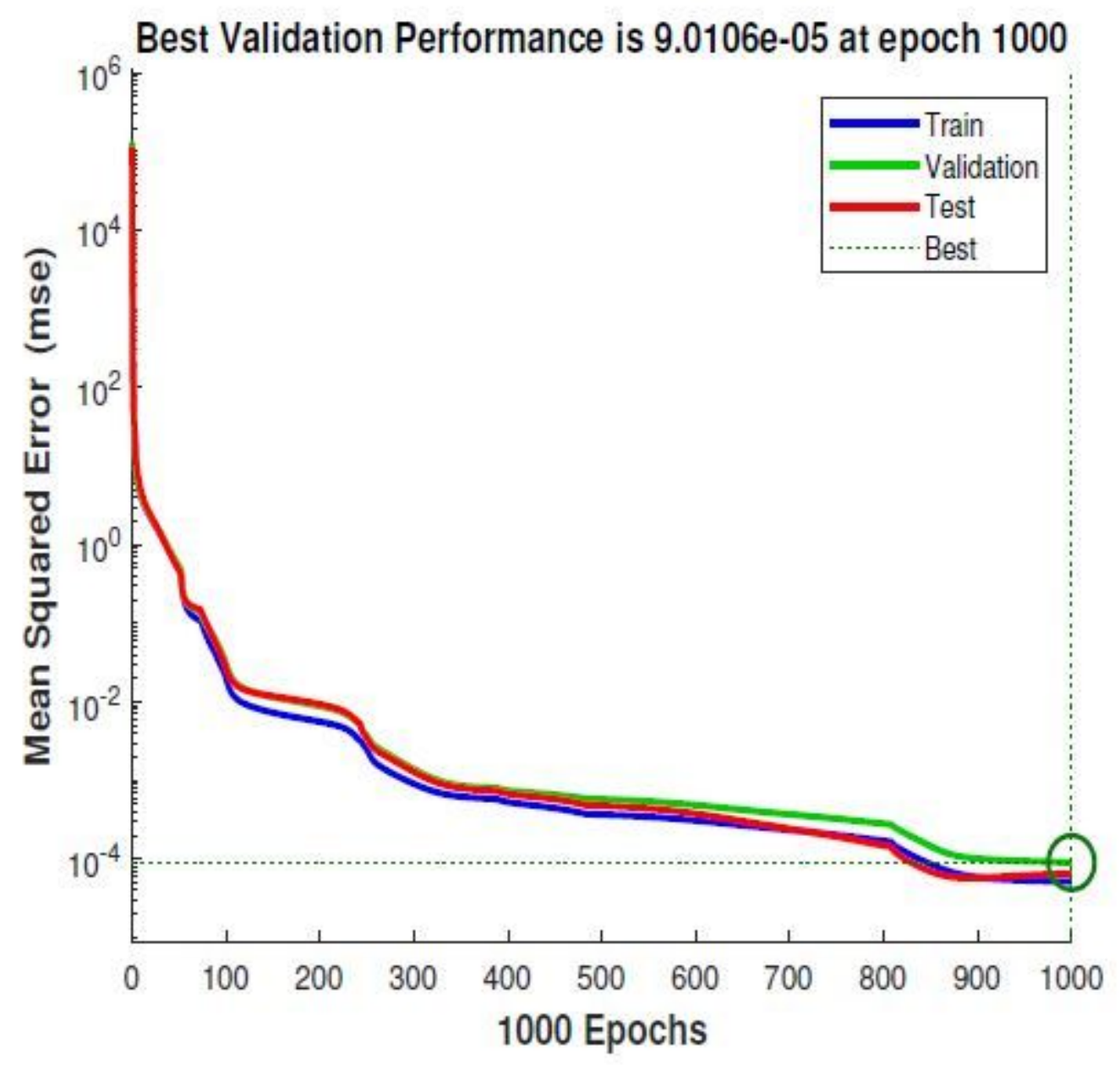

Figure 7

The performance of the Neural Network. 


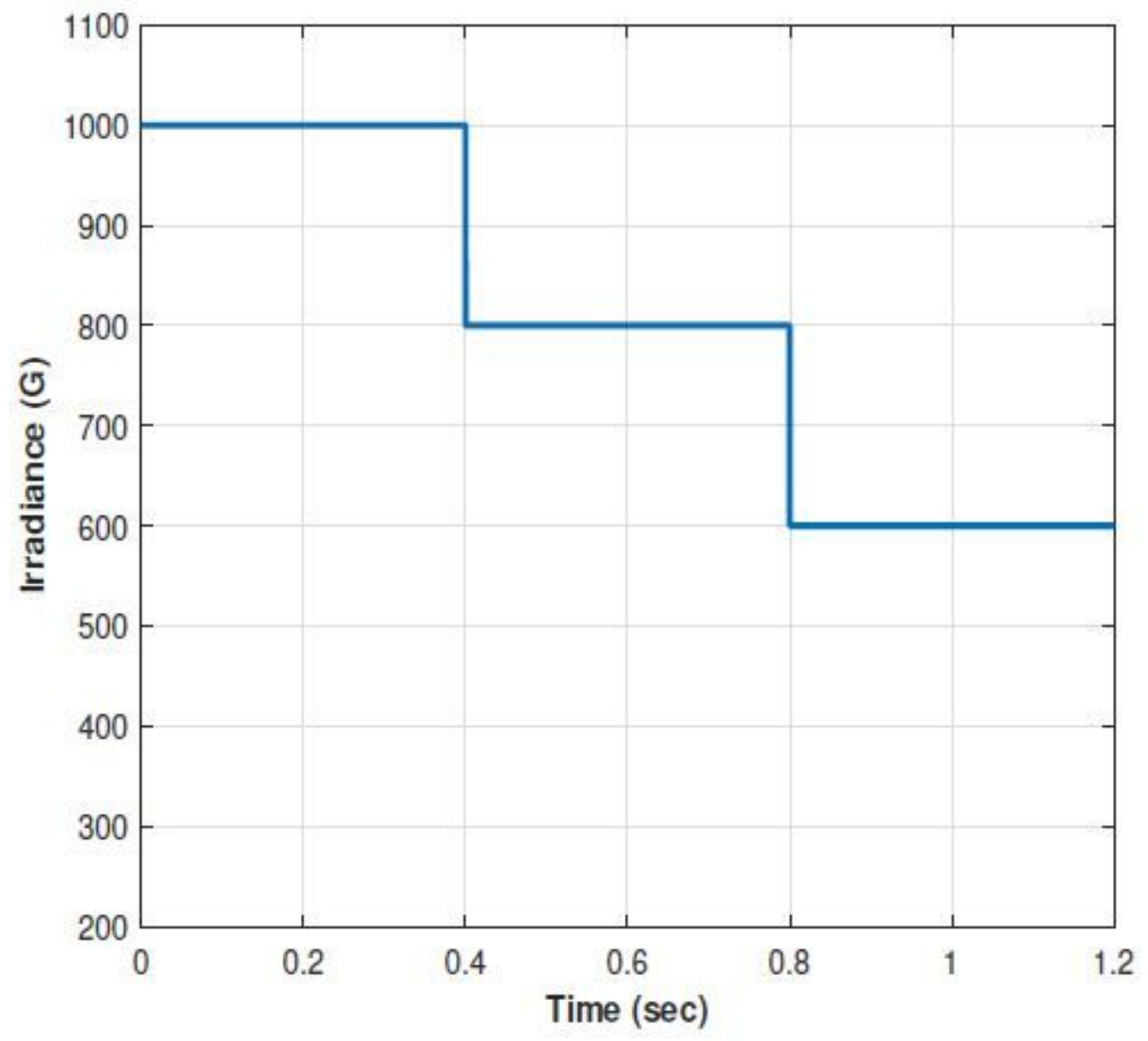

Figure 8

The Input irradiance pattern. 


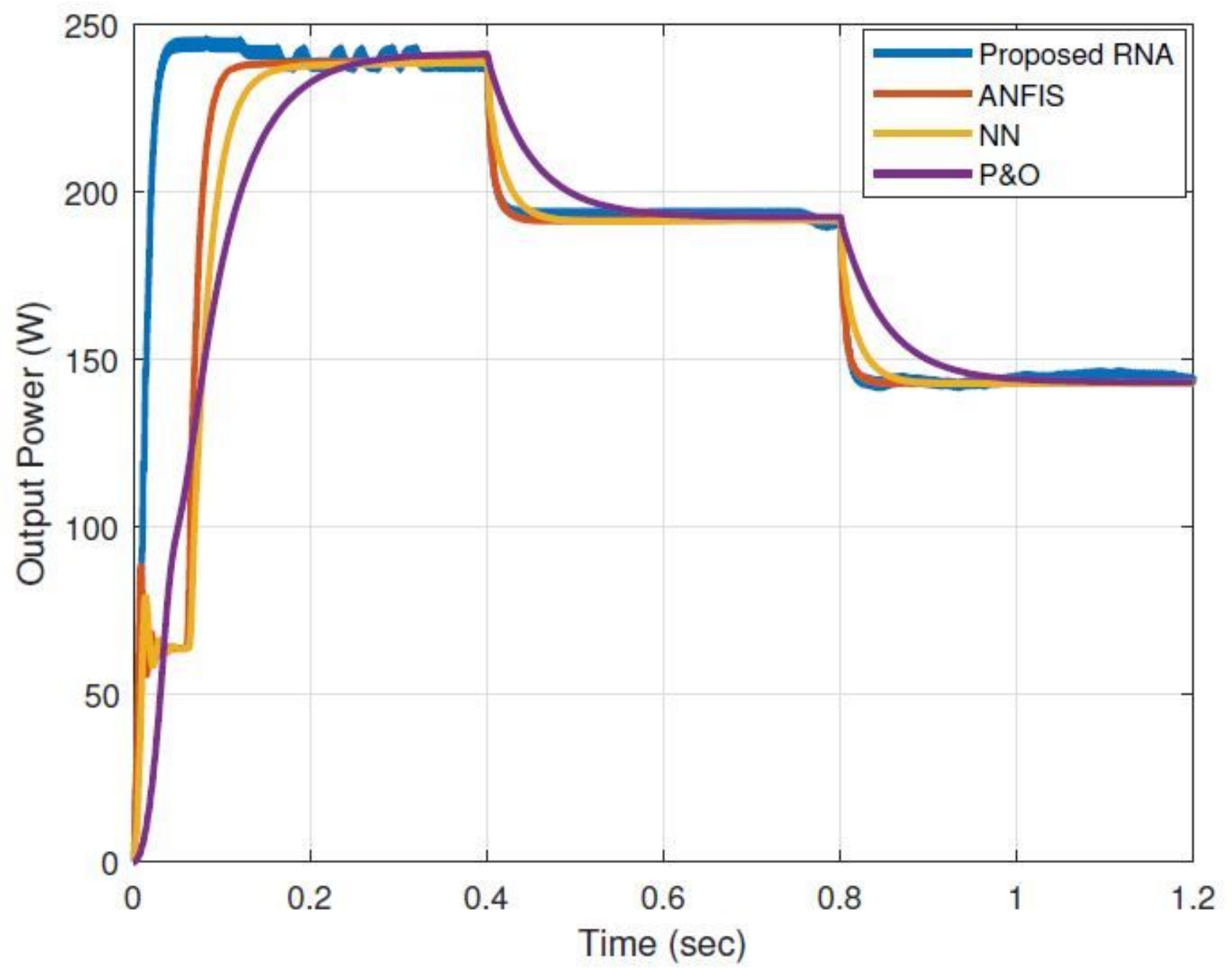

Figure 9

The output power of the proposed RNA algorithm. 


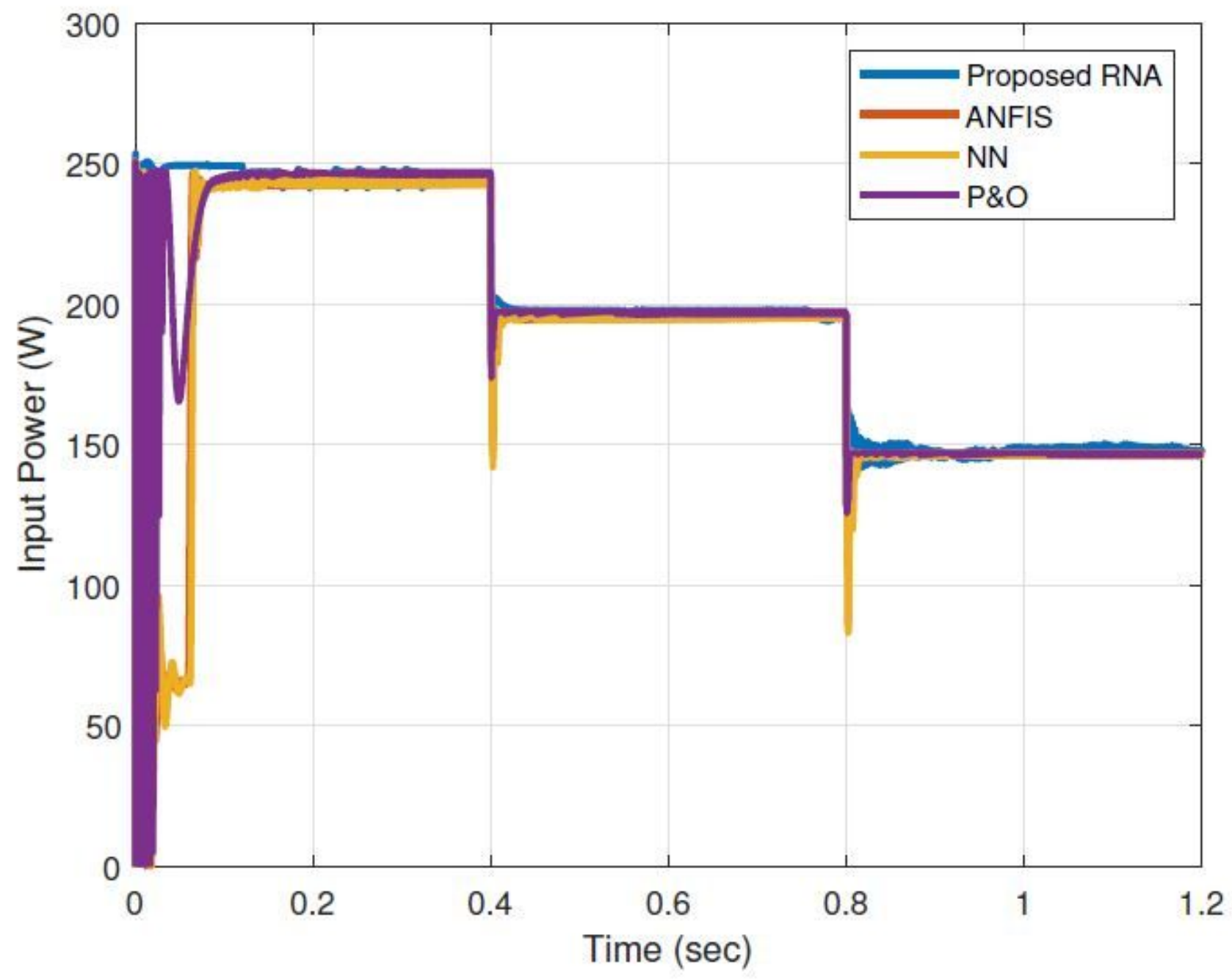

Figure 10

The PV power of the proposed RNA algorithm. 


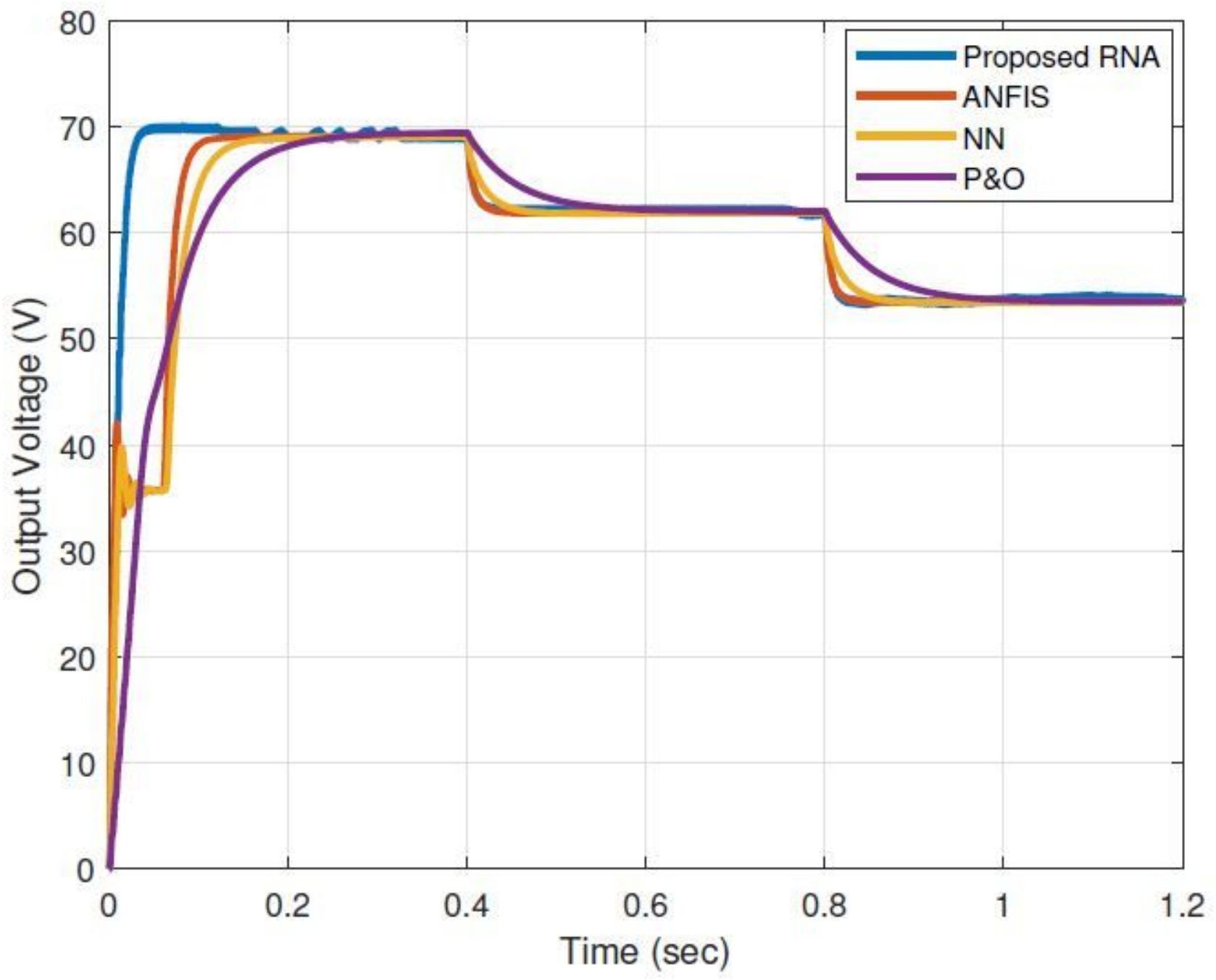

Figure 11

The output voltage of the proposed RNA algorithm. 


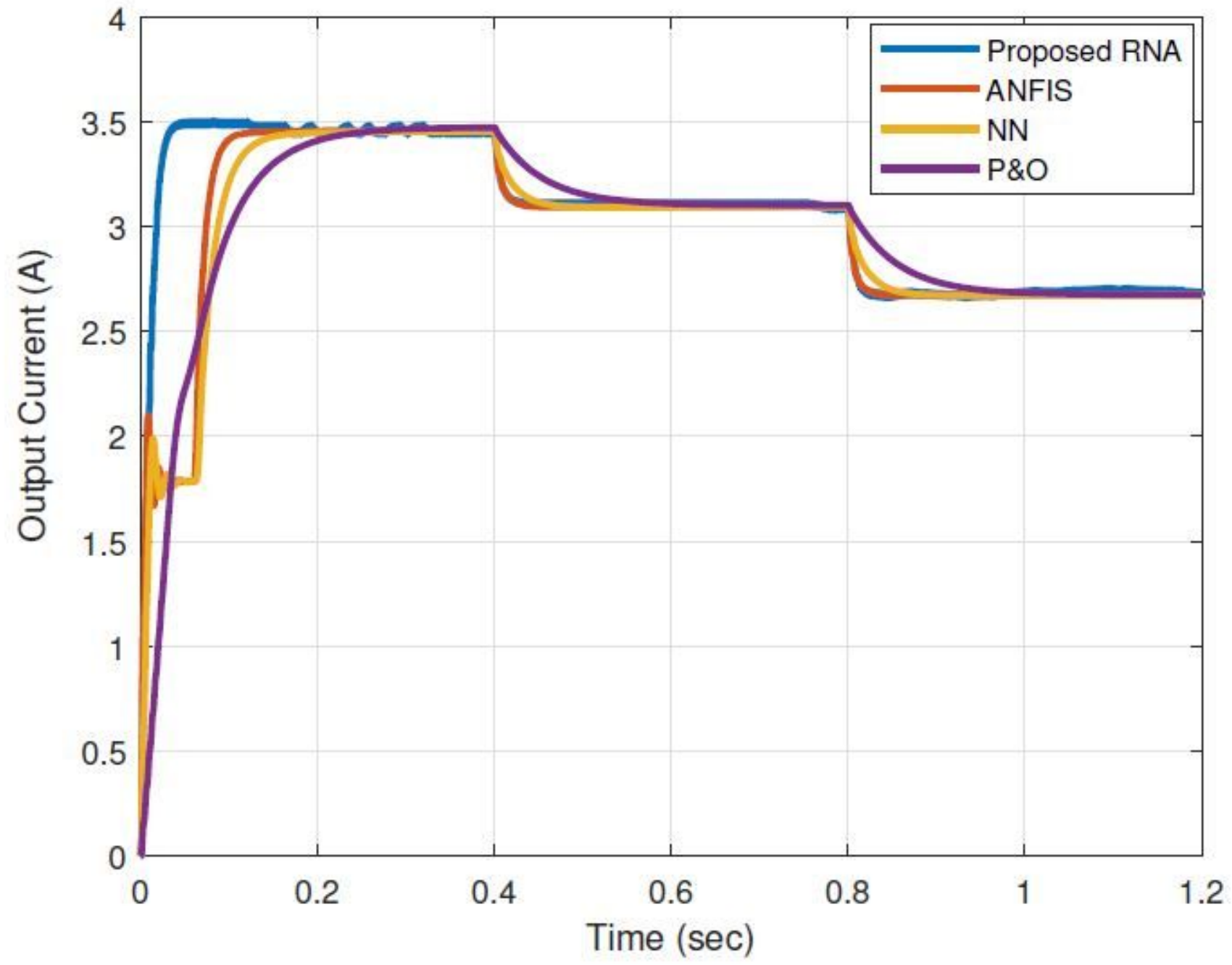

Figure 12

The output current of the proposed RNA algorithm. 